\title{
ANTES QUE O TEMPO APAGUE: MEMÓRIAS DA MINHA ALFABETIZAÇÃO*
}

\author{
Luciene Teodoro das Chagas Passos (SEMED/ROO)
}

Sentada em uma cadeira a pensar sobre o processo de alfabetização, veio a minha memória o período em que fui alfabetizada. E, percebi que é comum ouvir professoras falarem sobre o processo de alfabetização dos alunos. Porém, refleti que é raro, uma professora trazer a memória à alfabetização dela, ou seja, não é tão frequente assim. Haja vista que as lembranças podem se encontrar com diversas concepções adquiridas ao longo da vida. $E$, isso pode causar variados sentimentos. Mas, acredito que as experiências são melhores aproveitadas quando essas são compartilhadas. Por isso, proponho-me a voltar ao meu passado para poder contribuir com algumas pessoas envolvidas no processo de alfabetização, a fim de que certas reflexões possam ser realizadas no presente.

Para relembrar do meu processo de alfabetização, faz-se necessário trazer a memória o ano de 1986, pois nesse referido ano a minha família enfrenta várias dificuldades financeiras relacionadas à saúde do meu pai. Pois, ele era o único provedor da família e foi acometido por um Acidente Vascular Cerebral (AVC). Por esse motivo, a minha mãe sentia-se muito triste, porque ela não conhecia as 'letras' e nem dinheiro.

Naquele período, por diversas vezes, ela lavava roupas de algumas pessoas nas minas da cidade, a fim de manter o sustento da família. Todavia, quando ela recebia o pagamento, raramente o valor dava para comprar um pacote de arroz. Lembro-me de vê-la chorando, por muitas vezes, a falar que ela era uma "besta" por não conseguir combinar nem um trabalho com os outros.

Nas idas e vindas da saúde do meu pai, ele acabou por falecer. E, a minha mãe ficou com a responsabilidade de terminar de criar os quatro fiIhos, sozinha, sem estudo e sem trabalho. Visto que na nossa pequena cidade, no interior de Mato Grosso, nessa época, uma das poucas opções de trabalho que existia na cidade era o de cortar cana, ou seja, ser boia-fria. Então, ela começou a enfrentar a árdua rotina em um canavial, levando consigo o meu irmão caçula, que ela ainda amamentava no seio. Meus ir-

*DOI - 10.29388/978-65-86678-68-0-0-f.221-226 
mãos maiores iam à escola e eu ficava em casa trancada até eles chegarem do colégio.

Certo dia, a minha irmã Piedade começou a chorar na aula e o professor dela sem saber o motivo do choro, brigou com ela, ameaçando chamar a diretora caso ela não parasse de chorar. Entretanto, ela não conseguia segurar as lágrimas e o professor Inflexível levou-a à diretoria.

Quando ela chegou à sala da diretora, ela foi questionada pela gestora sobre o motivo do choro e ela contou que o choro era porque estava com dó da irmã, que estava em casa sozinha, querendo comer e se ela inventasse de esquentar a comida, poderia morrer queimada. Diante do relato da minha irmã, a diretora fez a promessa de ir a nossa casa, com objetivo de ver como eu estava e levaria um pouco de merenda para eu me alimentar. E, assim a diretora fez.

De repente, eu ouvi alguém bater à porta. Fiquei muito assustada, pois a minha mãe sempre falava para eu nunca perguntar quem era e, prin cipalmente, jamais abrir as janelas. Mas, naquele dia, eu não obedeci. Aliás, nunca havia ocorrido um episódio daquele. $E$, assim, eu olhei pela fresta da porta e vi que era uma mulher. Perguntei o que ela queria e ela falou "sou a Sensibilidade, diretora da escola da sua irmã Piedade. Você está com fome?". Então, lembrei que mamãe dizia que não era para nós nunca dizer isso, pois ela trabalhava muito para nós nunca passar fome. Porém, perguntei: - o que a senhora trouxe aí?. Ela respondeu: - eu trouxe uma merenda para você.

Naquele instante, apressadamente, abri a janela, peguei a vasilha de sopa e comi rapidamente. Enquanto, eu me alimentava, a diretora ficou a observar-me com um olhar de pena. Num impulso do momento, ela perguntou para mim, se eu queria ir à escola. Respondi de pronto que sim. Hoje, penso que aos quatro anos de idade, diante daquele convite eu poderia ter sido levada por qualquer um, pois a alegria foi tão radiante que eu corri para a porta, a fim de seguir com aquela amável senhora.

Após muita conversa, ela foi embora, prometendo que voltaria, com intuito de pedir a minha mãe para deixar eu frequentar a escola também. $E$, eu fiquei a sonhar com a possibilidade de ir ao colégio todos os dias com meus irmãos.

À tardinha, a minha mãe já estava em casa, quando a diretora Sensibilidade chegou e propôs a ela que eu poderia ir à escola todos os dias com os meus irmãos para eu nunca mais precisar ficar trancada sozinha dentro de casa. 
Depois que o pedido da gestora foi realizado, mamãe ficou muito contente, dizendo que ela conseguiria trabalhar melhor ao saber que eu estaria em boas mãos. Ademais, minha mãe começou a falar que o único problema era a falta dos materiais para eu escrever. Na minha ótica de primeira infância, eu só queria deixar de ficar sozinha em casa, pois o tempo que eu ficava só parecia uma eternidade.

Lembro-me que mamãe saia de madrugada e, por isso, ela deixava as roupas penduradas nos pregos da parede para nós irmos limpinhos à escola. E, assim meus irmãos arrumaram-me para o meu primeiro dia de aula. No caminho até o colégio, eles falavam da escola, dizendo para obedecer à professora para não ficar de castigo de joelhos no milho, entre outros tipos de intimidações.

Ao chegar à sala, a professora da pré-escola, falou para a diretora que não queria que eu ficasse lá. Lembro-me de ter chorado muito ao ouvir aquilo e, assim, a professora aproveitou para justificar que eu ainda era uma 'bebezona' para estar na escola. Contudo, a diretora, com muita tranquilidade, passava a mão nas minhas costas e explicava, quase que a implorar, que eu não tinha com quem ficar em casa. Além disso, garantiu que eu não atrapalharia a aula e ficaria sentada no chão, lá, no final da sala. Com muita insistência por parte da gestora, a professora aceitou a minha presença.

Com o passar dos dias na sala, confesso que a minha professora demonstrava ter nojo de mim. Pois, sempre que ela se aproximava de mim, meneava a cabeça, preferindo ignorar-me com frequência. Mas, naquela época, isso não me afetava tanto.

Recordo-me de permanecer, muitos dias, na escola sem fazer nada, aliás, fazia algumas coisas, tais como: observar os colegas realizando as atividades; a professora ensinando-os a copiar; sair para lanchar e, principalmente, ser repreendida pela professora, todas as vezes que eu inventava de levantar do meu cantinho no chão da sala.

Certo dia, falei para mamãe que eu precisava de um caderno, pois, na minha mente, a professora gostaria de mim, quando eu tivesse um caderno para escrever. Então, recebi a promessa da minha mãe que eu ganharia um caderno, assim que ela recebesse o pagamento. Quando mamãe recebeu, ela comprou um caderno, lápis preto e lápis de cor. Dessa maneira, comecei a copiar o que a professora escrevia no quadro.

Um dia, a educadora parou e pegou o meu caderno, olhou para mim e comentou que eu sabia copiar as letras do quadro. Daquele dia em diante, ela começou a jogar as cópias xerocopiadas para mim, enquanto ela 
distribuía aos demais. Eu pegava as folhas e ia tentando fazer. Confesso que eu sonhava com o dia que aquela professora pudesse pegar na minha mão para me ensinar também (choro). Todavia, isso nunca ocorreu.

Com o passar do tempo, a professora começou a passar algumas lições de pontilhados com letras manuscritas para eu fazer em casa. Recordo-me de passar horas e horas a fazer aquelas atividades. E, quando chegava à escola, a professora recolhia o caderno de todos, mas o meu ela só olhava e dizia que estava certo. Isso era o máximo para mim, pois eu chegava a casa e contava para todos que a professora nem corrigia o meu caderno, porque eu era muito sabida e não errava nada. Ah! Como é interessante perceber a inocência de criança, pois eu não conseguia perceber, por meio daquela atitude, que ela não me considerava sua aluna.

Enquanto na escola eu aprendia observando e realizando as atividades que a mim eram ofertadas, fora do ambiente escolar eu começava a ler tudo o que via pela frente, desde os rótulos de alimentos a folhas de revistas, jornais e livros postos em banheiros para outros fins de higiene na época.

Agora surgi, na minha memória, a lembrança de minha querida mãe a mostrar orgulhosamente o meu caderno para todas as pessoas que frequentavam a nossa casa. Puxa! Hoje, eu consigo perceber o quanto a família é importante nesse processo de alfabetização.

Em meio à empolgação de estar a ler, num certo dia, a professora estava a tomar a lição das famílias alfabéticas fixadas acima do quadro. Pois havia muitos cartazes colados nas paredes da sala de aula e na parte superior do quadro. E, eu comecei a falar que eu sabia ler. Na verdade, eu falava assim: "Tia deixa eu, deixa eu". Ela olhou para mim, com uma cara de deboche e falou: "Está bem negrinha. Vamos ver se você sabe mesmo".

Naquela hora, senti um frio na barriga ao ouvir a batida da régua de madeira no quadro. Entretanto, comecei a ler as palavras conforme a régua era posicionada. Ao término, ela falou para a classe: "vejam só a negrinha está sabendo mais do que vocês". Recordo-me que ela ficou emocionada, pois eu ainda consigo se lembrar daquele olhar que ela olhou para mim naquele dia, pois era um olhar diferente dos anteriores.

Desse modo, ela pediu para que uma das crianças fosse chamar a diretora, a fim de que ela contemplasse que eu estava a ler. Rapidamente, a Sensibilidade chegou. A professora começou a tomar a lição de mim. E, eu lia com facilidade. É incrível o que a memória faz. Nesse momento, é como se voltasse ao tempo e vivesse aquele momento novamente. Visto que con- 
sigo ter claramente a visão da gestora a chorar de emoção em me ver a ler aquelas palavras.

Naquele momento, a Sensibilidade perguntou para a professora: "Será que agora ela merece uma cadeira na sua sala, professora?". E, a professora sacudiu a cabeça a confirmar que sim. Daquele dia em diante, a professora começou a tratar-me melhor, chegando até a trazer lápis e borracha para mim.

No final do ano letivo, a diretora conversou comigo, dizendo que eu continuaria com a professora no outro ano, porque eu tinha aprendido bastante e ajudaria a professora a ensinar os outros alunos que chegariam. Recordo-me de ouvir, naquele diálogo, a Sensibilidade falar no meu ouvido: "em breve você será uma professora também".

Ah! Não poderia finalizar sem relatar que eu fiquei nessa sala com a professora por quase dois anos até completar a idade de ir para a turma da $1^{\circ}$ série do Ensino Fundamental. E foi assim que acabei descobrindo que, a minha professora ensinou-me diversas lições. Mas, eu também a ensinei algo importantíssimo, ou seja, ensinei-a que, sempre, é importante ter a Sensibilidade por perto. Pois acredito que se a diretora não tivesse tido a sensibilidade, naquele dia, o qual ela me viu, na minha casa sozinha. Com certeza, eu não estaria aqui compartilhando essas memórias do meu tempo de alfabetização e reafirmando o discurso do grande educador Paulo Freire (1987, p. 87), no qual ele afirma que a "Educação não transforma o mundo. Educação muda as pessoas. Pessoas transformam o mundo".

\section{Referências}

FREIRE, Paulo. Pedagogia do Oprimido. Rio de Janeiro: Paz e Terra, 1987. 